\title{
GSK3-beta as a candidate therapeutic target in soft tissue sarcomas
}

\author{
S. Verbeke ${ }^{1,2}$, R. Perret ${ }^{3}$, V. Chaire ${ }^{1,2}$, E. Richard ${ }^{2}$, V. Velasco ${ }^{3}$, F. Giles ${ }^{4}$, L. Cavalcante ${ }^{4}$ and A. Italiano ${ }^{1,2,5^{*}}$ (D)
}

\begin{abstract}
Soft tissue sarcoma (STS) is a predominantly fatal rare malignancy with inadequate treatment options. Glycogen synthase kinase $3 \beta$ (GSK-3 3 ) is an emerging target in human malignancies. Its therapeutic relevance in STS is unknown. We analyzed the prognostic impact of GSK-3 $\beta$ gene and protein expression in two independent cohorts of patients with STS. We then treated STS cell lines and mice xenografts with a novel GSK-3 inhibitor 9-ING-41 alone or in combination with chemotherapy. We demonstrated that 9-ING-41 treatment induced significant STS cells apoptosis and was synergistic in vivo when combined with chemotherapy. Mechanistically, 9-ING-41 induces significant apoptosis of STS cells via suppression of NF-kB-mediated X-linked inhibitor of apoptosis protein (XIAP) expression. These data support the inclusion of patients with STS in clinical studies of 9-ING-41 alone and in combination with chemotherapy.
\end{abstract}

Keywords: Glycogen synthase kinase 3 $\beta$, Soft tissue sarcomas, 9-ING-41

To the Editor

The prognosis of patients with advanced STS is extremely poor with a median overall survival of less than 18 months [1, 2]. Identification of new therapeutic strategies is therefore an important medical need.

Glycogen synthase kinase-3 $\beta$ (GSK-3 $\beta$ ) has been shown to play an important role in tumor progression particularly through the modulation of oncogenes, cell cycle regulators and mediators of epithelial-mesenchymal transition [3]. Recent studies have also demonstrated that aberrant overexpression of GSK-3 $\beta$ promotes tumor growth and chemotherapy resistance in various solid tumors including pancreatic, colorectal and prostate cancer through differential effects on pro-survival NF- $\mathrm{kB}$ and c-Myc pathways as well as on TNF-related apoptosis-inducing ligand (TRAIL) and p53-mediated apoptotic mechanisms [4-6]. GSK-3 $\beta$ represents therefore an important therapeutic target in human malignancies.

*Correspondence: a.italiano@bordeaux.unicancer.fr

1 Sarcoma Unit, Institut Bergonié, 229 cours de l'Argonne, 33000 Bordeaux, France

Full list of author information is available at the end of the article
9-ING-41 is a small molecule potent selective GSK-3 $\beta$ inhibitor with antitumor activity in several epithelial tumor models as shown by the interim results of the first clinical trial reported in patients with refractory cancers. Five other phase 2 clinical trials are ongoing in salivary gland carcinoma, myelofibrosis, pancreatic adenocarcinoma and pediatric patients with advanced malignancies (https://clinicaltrials.gov/ct2/results?cond=\&term = 9 ING41\&cntry $=\&$ state $=\&$ city $=\&$ dist $=) \quad[7-9] . \quad$ We report here the first study investigating the therapeutic potential of GSK-3 $\beta$ targeting with 9-ING-41 in STS (see Additional file 1: Methods).

We first used the Gene Expression Profiling Interactive Analysis (GEPIA), a web-based interactive database that compiles the standardized analysis of RNA-Seq data from 9736 tumors and 8587 normal samples based on The Cancer Genome Atlas (TCGA) and GenotypeTissue Expression (GTEx) databases. We found that high GSK3 $\beta$ gene expression was significantly associated with worse disease-free survival (log-rank test, $\mathrm{p}=0.0088$, Additional file 1: Fig. 1). To confirm the prognostic value of GSK3 $\beta$ expression, we analyzed by immunohistochemistry a series of 402 patients with STS (Fig. 1A and Additional file 1: Tables 1 and 2). We original author(s) and the source, provide a link to the Creative Commons licence, and indicate if changes were made. The images or other third party material in this article are included in the article's Creative Commons licence, unless indicated otherwise in a credit line to the material. If material is not included in the article's Creative Commons licence and your intended use is not permitted by statutory regulation or exceeds the permitted use, you will need to obtain permission directly from the copyright holder. To view a copy of this licence, visit http://creativecommons.org/licenses/by/4.0/. The Creative Commons Public Domain Dedication waiver (http://creativeco mmons.org/publicdomain/zero/1.0/) applies to the data made available in this article, unless otherwise stated in a credit line to the data. 
(See figure on next page.)

Fig. 1 A Examples of GSK3 $\beta$ staining intensity in soft tissue sarcomas. GSK3 $\beta$ was evaluated semi-quantitatively including percentage (0-100\%) and intensity $(0=$ null, $1=$ low, $2=$ moderate, $3=$ strong). B Kaplan-Meier curves of metastases-free survival in 402 patients with soft tissue sarcomas according to GSK3 $\beta$ expression (blue line: low expression, $<50 \%$ of tumor cells $n=296$; green line: high expression: $\geq 50 \%$ of tumor cells $n=106$ ). C Kaplan-Meier curves of metastases-free survival in 268 patients with grade 3 soft tissue sarcomas according to GSK3 3 expression (blue line: low expression, $<50 \%$ of tumor cells $n=200$; green line: high expression: $\geq 50 \%$ of tumor cells $n=68$ )

observed positive expression of GSK3 $\beta$ in 220 (54.7\%) cases. High expression of GSK3 $\beta$ ( $>50 \%$ of tumor cells) was significantly associated with poor prognosis (median metastases-free survival 139 months versus not reached, $p=0.02$, Fig. $1 B$ ) supporting the hypothesis that GSK3 $\beta$ may represent a potential therapeutic target. As shown in Fig. 1C, GSK3 $\beta$ protein expression provided extra information to further refine the prognosis of patients besides histological grade which is considered the most significant predictor of outcome.

9-ING-41 is a first-in-class, maleimide-based small molecule potent selective GSK3 $\beta$ inhibitor that has recently entered into clinical development. To examine its antitumor effect on STS, a panel of 20 STS cell lines were plated and treated with increasing concentrations of 9-ING-41 for $72 \mathrm{~h}$. We showed that pharmacological inhibition of GSK3 $\beta$ by 9 -ING-41 suppressed the viability of all the 20 STS cell lines encompassing several histological subtypes with IC50 values ranging from 0.1 to $0.6 \mu \mathrm{M}$ (Additional file 1: Table 3, Additional file 1: Fig. 2A).

Then, we demonstrated that 9-ING-41 suppresses cell viability through induction of apoptosis in a large panel of STS in vitro by using annexin V/PI, and immunoblots of apoptotic markers such as phospho- $\gamma \mathrm{H} 2 \mathrm{AX}$, cleavedCaspase- 3 and cleaved-PARP confirming the phenotype of significant cell death in 9-ING-41-treated cells (Additional file 1: Figs. 2B and 3).

GSK3 $\beta$ controls many cellular process including the survival NF-kappaB pathway. Therefore, we assessed by Western blot the activation of the IKB kinase (IKK), a key protein involved in the translocation of NF-kappaB to the nucleus. As shown in Additional file 1: Fig. 4, the phosphorylation of $\mathrm{IKK} \alpha / \beta$ at serine $176 / 177$ is decreased after $24 \mathrm{~h}$ of 9-ING-41 treatment in different STS cell lines suggesting an inhibition of the NF- $\mathrm{kB}$ pathway. To confirm these results, the expression of three NF- $\mathrm{kB}$ target genes involved in anti-apoptotic effect, $\mathrm{Bcl}-2, \mathrm{Bcl}$ $X L$ and XIAP, was examined. Although immunoblots revealed no significant changes in expression of Bcl-2 and Bcl-XL, XIAP expression was reduced in almost all cell lines tested (Additional file 1: Fig. 4). These data suggest that 9-ING-41 induces apoptosis in STS cell lines through the inhibition of NF- $\mathrm{kB}$ pathway and a subsequent decreased expression of the anti-apoptotic gene XIAP.
We next evaluated the effect of 9-ING-41 in vivo by using the IB115 liposarcoma model. Mice were randomized in 4 groups and treated by intraperitoneal injection with vehicle, 9-ING-41, doxorubicin (the standard of care for STS) or combination of both drugs. As shown in Fig. 2, the tumors expanded aggressively in vehicle-treated animals, whereas in monotherapy a slight decrease of tumor growth was observed for 9-ING-41- or doxorubicin-treated mice. On the other hand, the combination treatment caused a significant decrease in tumor growth suggesting that 9 -ING-41 can potentiate the effect of doxorubicin even with a low dose of chemotherapy without significant signs of toxicity as shown by the stable body weight of the mice (Fig. 2B).

By analyzing two large independent data sets, we show here than GSK3 $\beta$ expression both at the gene and protein expression level is associated with increased risk of metastatic relapse and adverse outcome in STS patients suggesting an important role in sarcoma tumorigenesis and a potential role as a therapeutic target. Moreover, instead of using the commercially available toolkit GSK-3 $\beta$ inhibitors, which are not amenable for clinical studies, we decided here to investigate 9-ING-41, a first-in-class GSK-3 $\beta$ inhibitor which has recently entered clinical development in cancer patients. Preclinical studies have shown that 9-ING-41 induces significant apoptosis of cancer cell survival via suppression of NF-kB-mediated $\mathrm{B}$ cell lymphoma 2 (Bcl-2) and XIAP expression in leukemia and solid tumors $[10,11]$. The NFkB transcription factor family is a highly conserved group of proteins playing an important role in the regulation of the cell physiology such as differentiation, apoptosis and survival. Pharmacological NFKB inhibition has been shown to reduce cell growth in a spectrum of soft tissue sarcomas [12]. Here, we have shown that 9-ING-41 led to a decreased expression of the antiapoptotic molecule, XIAP, and resulted in an increased apoptosis as shown by PARP cleavage and caspase activation assay in STS cells. This suggests that 9-ING-41 may represent a candidate for the targeted therapy of STS. 9-ING-41 is currently under investigation as a single agent and in combination with chemotherapy in cancer patients with advanced disease [13]. Preliminary results have shown a good safety profile and promising early signs of clinical activity in several solid tumors including melanomas and pancreatic 
A
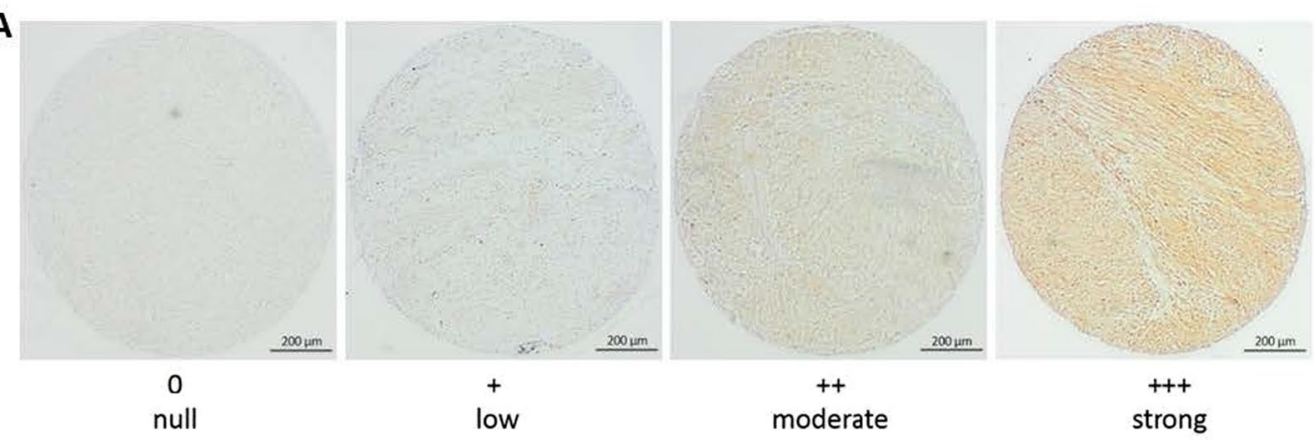

B

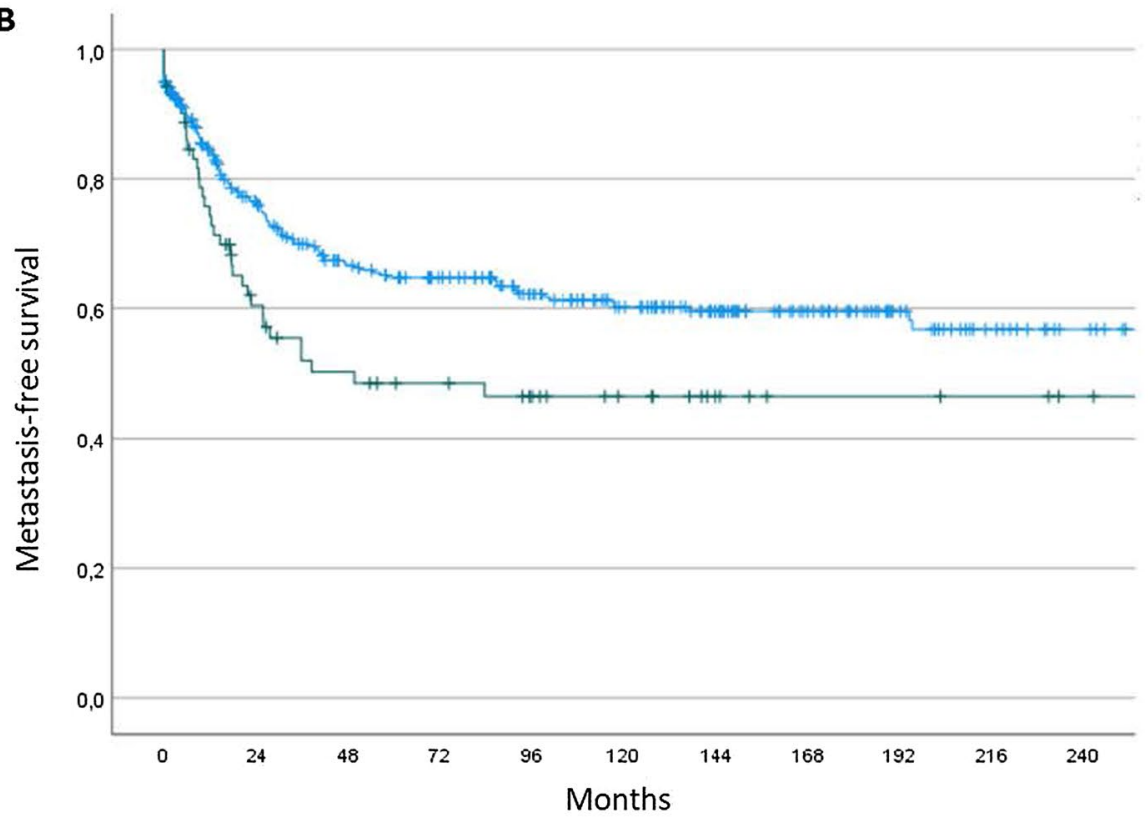

C

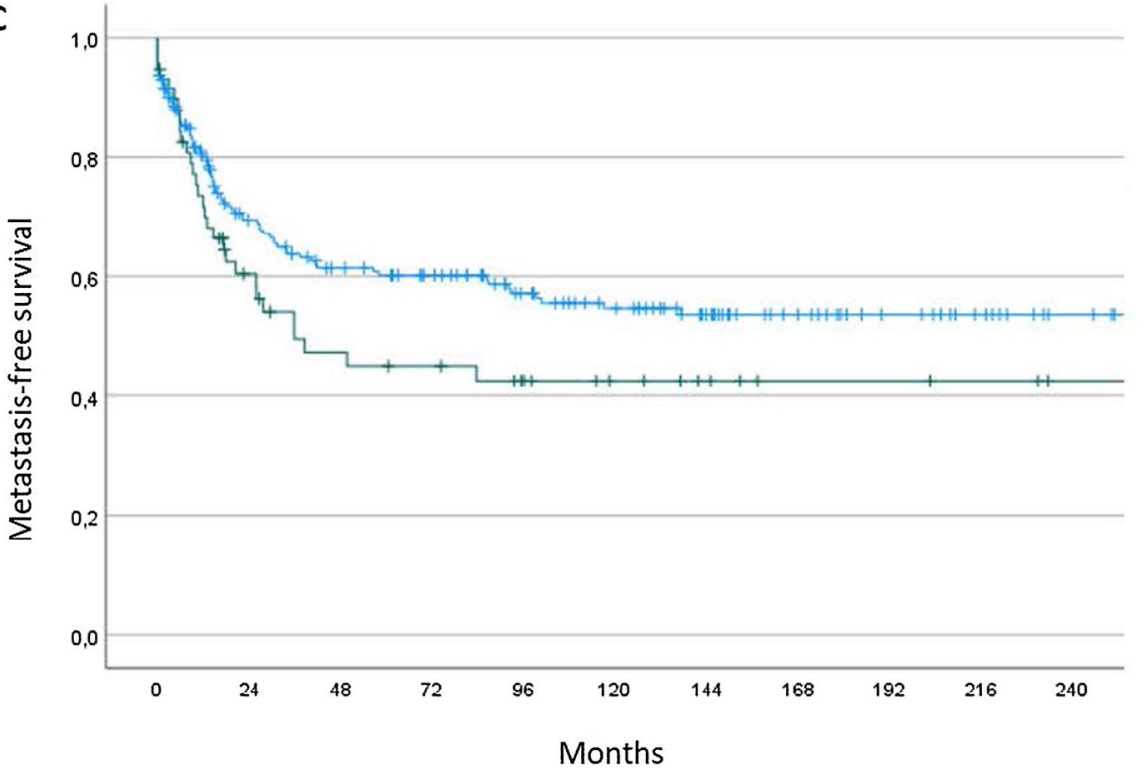

Fig. 1 (See legend on previous page.) 

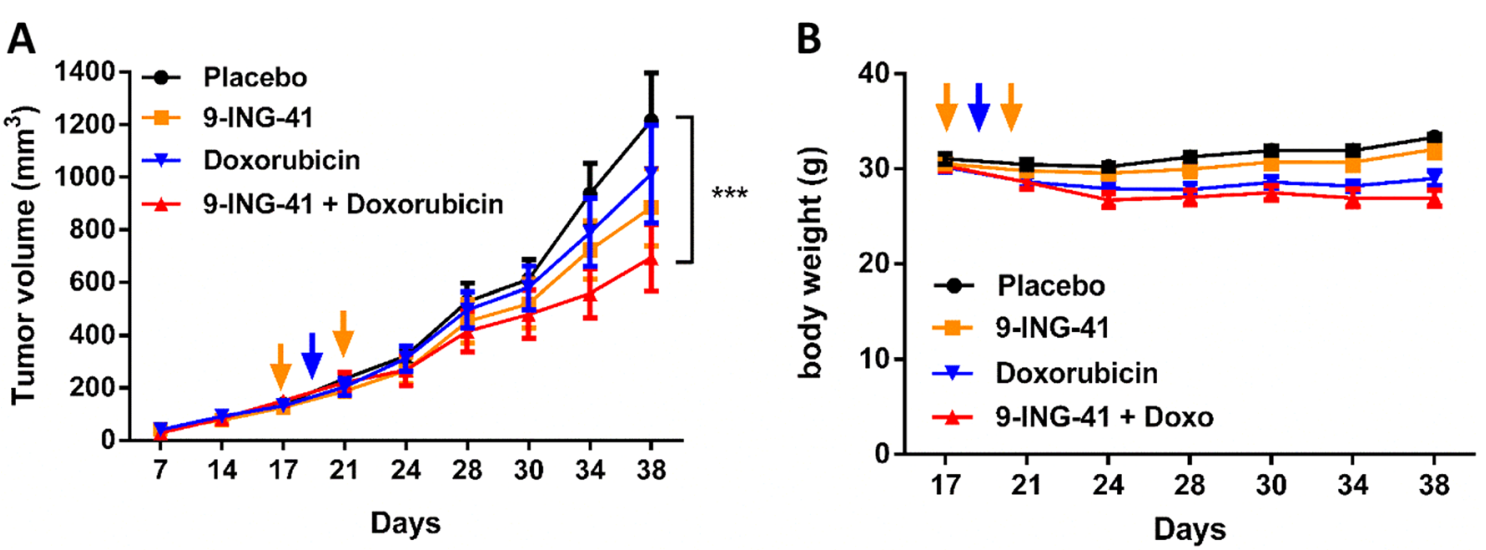

Fig. 2 In vivo effect of GSK3 $\beta$ inhibitor 9-ING-41 in soft tissue sarcoma. IB115 liposarcoma cells were xenografted in NSG mice. Once tumors reached $100 \mathrm{~mm}^{3}$ (day 17), mice were treated either with placebo (9 mice) or with two injections of 9-ING-41 at $70 \mathrm{mg} / \mathrm{kg}$ (orange arrow, 7 mice) or one injection of Doxorubicin at $1 \mathrm{mg} / \mathrm{kg}$ (blue arrow, 6 mice) or both drugs (6 mice). Tumor growth $(\mathbf{A})$ and mice body weight (B) were monitored until day 38 and analyzed with GraphPad prism software using two-way ANOVA test and Bonferroni post-hoc test $\left({ }^{* *} p<0.001\right)$. Combination treatment of 9-ING-41 and doxorubicin reduces significantly tumors volume

cancers. Based on these results, a clinical trial investigating 9-ING-41 in sarcoma patients will be conducted.

\section{Abbreviations}

GEPIA: Gene Expression Profiling Interactive Analysis; GSK-3ß: Glycogen synthase kinase 3 $\beta$; GTEx: Genotype-Tissue Expression; IKK: The IKB kinase; TCGA :The Cancer Genome Atlas; TRAIL: TNF-related apoptosis-inducing ligand; STS: Soft tissue sarcomas; XIAP: X-linked inhibitor of apoptosis protein.

\section{Supplementary Information}

The online version contains supplementary material available at https://doi. org/10.1186/s13045-021-01215-x.

Additional file 1: Supplementary methods and results.

Acknowledgements

9-ING-41 was supplied by Actuate Therapeutics

\section{Authors' contributions}

Al, FG, LC and SV contributed to conceptualization; SV, VC, ER, WV and RP provided methodology; Al, SV and RP performed validation; SV carried out formal analysis and visualization; SV, VC, ER and VV performed investigation; AI, DD and FG provided resources; SV and Al performed writing —original draft preparation; Al, FG and LC performed writing — review and editing; Al contributed to supervision and project administration. All authors read and approved the final manuscript.

\section{Funding}

ACTUATE THERAPEUTICS, SIRIC BRIO.

\section{Availability of data and materials}

Source data are available on request to the corresponding author.

\section{Declarations}

\section{Ethics approval and consent to participate}

This study has been approved by the ethic committee for animal studies at the University of Bordeaux. The animal study was conducted according to the French and European Union guidelines for animal experimentation (RD
1201/05, RD 53/2013 and 86/609/CEE, respectively) and approved by the institutional animal use and care committee under project license APAFiS \#17900-2018112722234037. The study was also approved by the Institutional Review Board of Institut Bergonié.

\section{Consent for publication}

Not applicable.

\section{Competing interests}

FG and LC are consultants to Actuate Therapeutics.

\section{Author details}

'Sarcoma Unit, Institut Bergonié, 229 cours de l'Argonne, 33000 Bordeaux, France. ${ }^{2}$ INSERM, U1218, Bordeaux, France. ${ }^{3}$ Department of Pathology, Institut Bergonié, Bordeaux, France. ${ }^{4}$ Actuate Therapeutics, Fort Worth, TX, USA. ${ }^{5}$ Faculty of Medicine, University of Bordeaux, Bordeaux, France.

Received: 9 September 2021 Accepted: 9 November 2021

Published online: 02 December 2021

\section{References}

1. Savina M, Le Cesne A, Blay JY, Ray-Coquard I, Mir O, Toulmonde M, Cousin S, Terrier P, Ranchere-Vince D, Meeus P, Stoeckle E, Honoré C, Sargos P, Sunyach MP, Le Péchoux C, Giraud A, Bellera C, Le Loarer F, Italiano A. Patterns of care and outcomes of patients with METAstatic soft tissue SARComa in a real-life setting: the METASARC observational study. BMC Med. 2017;15(1):78.

2. Amadeo B, Penel N, Coindre JM, Ray-Coquard I, Ligier K, Delafosse P, Bouvier AM, Plouvier S, Gallet J, Lacourt A, Coureau G, Monnereau A, Mathoulin-Pélissier S, Desandes E. Incidence and time trends of sarcoma (2000-2013): results from the French network of cancer registries (FRANCIM). BMC Cancer. 2020;20(1):190.

3. Saraswati AP, Ali Hussaini SM, Krishna NH, Babu BN, Kamal A. Glycogen synthase kinase-3 and its inhibitors: potential target for various therapeutic conditions. Eur J Med Chem. 2018;144:843-58.

4. Ougolkov AV, Fernandez-Zapico ME, Savoy DN, Urrutia RA, Billadeau DD. Glycogen synthase kinase-3beta participates in nuclear factor kappaB-mediated gene transcription and cell survival in pancreatic cancer cells. Cancer Res. 2005:65(6):2076-81.

5. Liao X, Zhang L, Thrasher JB, Du J, Li B. Glycogen synthase kinase-3beta suppression eliminates tumor necrosis factor-related apoptosis-inducing ligand resistance in prostate cancer. Mol Cancer Ther. 2003;2(11):1215-22. 
6. Tan J, Zhuang L, Leong HS, lyer NG, Liu ET, Yu Q. Pharmacologic modulation of glycogen synthase kinase-3beta promotes p53-dependent apoptosis through a direct Bax-mediated mitochondrial pathway in colorectal cancer cells. Cancer Res. 2005;65(19):9012-20.

7. Ugolkov A, Qiang W, Bondarenko G, Procissi D, Gaisina I, James CD, Chandler J, Kozikowski A, Gunosewoyo H, O'Halloran T, Raizer J, Mazar AP. Combination treatment with the GSK-3 inhibitor 9-ING-41 and CCNU cures orthotopic chemoresistant glioblastoma in patient-derived xenograft models. Transl Oncol. 2017;10(4):669-78.

8. Wu X, Stenson M, Abeykoon J, Nowakowski K, Zhang L, Lawson J, Wellik L, Li Y, Krull J, Wenzl K, Novak AJ, Ansell SM, Bishop GA, Billadeau DD, Peng KW, Giles F, Schmitt DM, Witzig TE. Targeting glycogen synthase kinase 3 for therapeutic benefit in lymphoma. Blood. 2019;134(4):363-73. https:// doi.org/10.1182/blood.2018874560.

9. Carneiro B, Cavalcante L, Bastos B, Powell SF, Ma WW, Sahebjam S, Harvey D, De Souza AL, Sachdev Dhawan M, Safran H, Giles FJ, Munster PN. Phase I study of 9-ing-41, a small molecule selective glycogen synthase kinase-3 beta (GSK-3 $\beta$ ) inhibitor, as a single agent and combined with chemotherapy, in patients with refractory tumors. J Clin Oncol. 2020;38(15_suppl):3507-3507.

10. Ougolkov AV, Bone ND, Fernandez-Zapico ME, Kay NE, Billadeau DD. Inhibition of glycogen synthase kinase-3 activity leads to epigenetic silencing of nuclear factor kappaB target genes and induction of apoptosis in chronic lymphocytic leukemia B cells. Blood. 2007;110(2):735-42. https:// doi.org/10.1182/blood-2006-12-060947.

11. Kuroki H, Anraku T, Kazama A, Bilim V, Tasaki M, Schmitt D, Mazar AP, Giles FJ, Ugolkov A, Tomita Y. 9-ING-41, a small molecule inhibitor of GSK-3beta, potentiates the effects of anticancer therapeutics in bladder cancer. Sci Rep. 2019;9:19977. https://doi.org/10.1038/s41598-019-56461-4.

12. Abe K, Yamamoto N, Domoto T, et al. Glycogen synthase kinase $3 \beta$ as a potential therapeutic target in synovial sarcoma and fibrosarcoma. Cancer Sci. 2020;111(2):429-40. https://doi.org/10.1111/cas.14271.

13. Duda P, Akula SM, Abrams SL, Steelman LS, Martelli AM, Cocco L, Ratti S, Candido S, Libra M, Montalto G, et al. Targeting GSK3 and associated signaling pathways involved in cancer. Cells. 2020;9:1110. https://doi.org/ 10.3390/cells9051110.

\section{Publisher's Note}

Springer Nature remains neutral with regard to jurisdictional claims in published maps and institutional affiliations.

Ready to submit your research? Choose BMC and benefit from:

- fast, convenient online submission

- thorough peer review by experienced researchers in your field

- rapid publication on acceptance

- support for research data, including large and complex data types

- gold Open Access which fosters wider collaboration and increased citations

- maximum visibility for your research: over 100M website views per year

At BMC, research is always in progress.

Learn more biomedcentral.com/submissions 